\title{
IMPLEMENTASI KEBIJAKAN RUANG TERBUKA HIJAU DI KOTA ADMINISTRASI JAKARTA UTARA PROVINSI DKI JAKARTA
}

\author{
Hendra Wijayanto ${ }^{1)}$ \\ Ratih Kurnia Hidayati ${ }^{2)}$ \\ 1), 2)Universitas 17 Agustus 1945 Jakarta \\ email: 1) hendra.pelajar@gmail.com \\ 2) ratihkurnia20@gmail.com
}

\begin{abstract}
City Government of Jakarta, especially Government of North Jakarta as the authorized party has critical role in managing green open space in accordance with Law No. 26/2007 on Green Open Space Arrangement. The presence of green open space is needed as a climate regulator so that the air and water circulation system can be well maintained to support the embodiment of healthy and sustainable city, as a shade, oxygen producer, rainwater absorber, provider of animal habitat, pollutant absorbent, and windbreak. Green open space can improve ground water quality, prevent flooding, reduce air pollution, and lower city temperatures. In addition, green open space can also be a place of recreation, media communications for citizens of the city, as well as an object of education, research, and training in studying nature. This study aims to analyze the implementation of Green Open Space policy in the area of Jakarta particularly in North Jakarta. This research is a qualitative descriptive research that aims to provide a systematic, thorough, detailed, and profound analysis of the implementation of green open space management in North Jakarta. Data collection techniques were conducted with interviews supported by data collection through document review and observation. This research uses qualitative interactive data analysis technique which includes data reduction, data presentation, and conclusion / verification. The data validity test is done by using source triangulation. The results present that the implementation of the provision of green open space in North Jakarta Administration City is still not optimal and realized by 5\% due to the use of land available for RTH does not function as the designation and the existence of some obstacles faced as weak supervision, land prices are expensive, improvement of undeveloped land and the lack of dissemination to the public. Therefore, this study recommend the need for a political will from the government, a review by the government to make Jakarta just as central government alone, and a tighter control by enforcement strict sanctions.
\end{abstract}

Keywords: Policy Implementation, Spatial Planning, Green Open Space.

\section{PENDAHULUAN}

Undang-Undang Nomor 26 Tahun 2007 tentang Penataan telah mengamanatkan bahwa setiap kota dalam rencana tata ruang wilayahnya diwajibkan untuk mengalokasikan sedikitnya 30\% dari ruang atau wilayahnya untuk RTH, dimana 20\% diperuntukkan bagi RTH publik dan 10\% diperuntukkan bagi RTH privat pada lahanlahan yang dimiliki oleh swasta atau masyarakat. Pengembangan, penataan, dan pemenuhan ruang terbuka hijau bagi seluruh komponen lingkungan hidup perkotaan menjadi tanggung jawab seluruh pemangku kepentingan baik pemerintah pusat, provinsi, atau daerah, swasta, dan masyarakat.

Untuk menciptakan pembangunan yang berwawasan lingkungan yang dalam hal ini terkait dengan ketersediaan RTH tidak hanya memerlukan perencanaan yang baik tetapi juga memerlukan pengawasan dalam implementasi atau pelaksanaan dari perencanaan tersebut. Pengawasan berorientasi pada tujuan organisasi, perencanaan dan pelaksanaannya.

Pengawasan dalam penyediaan RTH menjadi sangat penting seiring dengan 
pesatnya kemajuan dan perkembangan teknologi serta pembangunan- pembangunan di kota-kota besar yang ada di Indonesia saat ini.

Jakarta Utara merupakan bagian dari DKI Jakarta yang tidak luput dari pembangunan dan pengembangan wilayah. Meningkatnya aktivitas pembangunan serta perkembangan wilayah di Jakarta Utara berdampak pada meningkatnya dinamika penggunaan lahan. Luasan lahan yang relatif tetap tetapi permintaan lahan yang terus meningkat menyebabkan proses alih fungsi lahan terutama Ruang Terbuka Hijau di kawasan Jakarta Utara tidak terelakkan lagi.

BerdasarkandatadariSukuDinasPertama nan dan Pemakaman Jakarta Utara, pada tahun 2014 Jakarta Utara hanya memiliki lahan RTH sebesar 5\% dari luasan wilayahnya. Persentase luas RTH tersebut tentu masih jauh dari apa yang diamanatkan dalam undang-undang yang mengamanatkan proporsi ruang terbuka hijau pada wilayah kota paling sedikit 30\% dari luas wilayah kota (Pasal 29 Ayat 2 Undang-Undang Nomor 26 Tahun 2007 tentang Penataan Ruang).

Tujuan dari penelitian ini adalah untuk menganalisis mengenai implementasi kebijakan ruang terbuka hijau di Kota Administrasi Jakarta Utara, kendala-kendala yang dihadapi, dan upaya-upaya yang dilakukan untuk meningkatkan implementasi kebijakan ruang terbuka hijau di Kota Administrasi JakartaUtara

Untuk menganalisis dan menjawab permasalahan dalam penelitian ini digunakan beberapa teori yang relevan. Terkait dengan implementasi kebijakan, Grindle (dalam Subarsono, 2005:89) menjelaskan bahwa ada beberapa factor yang mempengaruhi implementasi kebijakan (dalam hal ini adalah implementasi kebijakan terkait penyediaan ruang terbuka hijau di Kota Administrasi Jakarta Utara), yang meliputi:

a. Isi kebijakan (content of policy) mencakup:

\section{Interest Affected/Kepentingan yang}

Mempengaruhi;

Dalam hal ini akan dilihat sejauh mana kepentingan kelompok sasaran yaitu masyarakat Kota Administrasi Jakarta Utara termuat dalam isi kebijakan penyediaan ruang terbuka hijau (RTH).

\section{Type of Benefits/TipeManfaat;}

Bagian ini lebih menekankan pada jenis manfaat yang diterima oleh kelompok sasaran baik pemerintah daerah maupun masyarakat Kota Administrasi Jakarta Utara terkait implementasi kebijakan penyediaan ruang terbuka hijau (RTH) di KotaAdministrasi Jakarta Utara.

3. Extent of Change Envision/Derajat Perubahan yang Ingin di Capai;

Dalam hal ini akan dilihat sejauh mana perubahan yang diinginkan dari kebijakan penyediaan ruang terbuka hijau (RTH) di Kota Administrasi Jakarta Utara.

\section{Site of Decision Making}

Letak Pengambilan Keputusan (Apakah letak sebuah program untuk mendukung kebijakan penyediaan ruang terbuka hijau (RTH) di Kota Administrasi Jakarta Utara sudah tepat);

\section{Program Implementors}

Pelaksana Program (Apakah sebuah program telah menyebutkan implementornya dengan rinci);

\section{Resources Committee}

Sumber-sumber Daya yang Digunakan, dalam hal ini adalah sumber-sumber daya yang dibutuhkan untuk mendukung 
kebijakan penyediaan ruang terbuka hijau (RTH) di Kota Administrasi Jakarta Utara.

b. Lingkungan implementasi (context of implementation) mencakup:

1. Power, Interest, and Strategy of Actor Involved

Kekuasaan, Kepentingan- kepentingan, dan Strategi dari Aktor yangTerlibat (Seberapa besar kekuasaan, kepentingan, dan strategi yang dimiliki oleh para stakeholders yang terlibat dalam implementasi kebijakan penyediaan ruang terbuka hijau (RTH) di Kota Administrasi Jakarta Utara);

2. Institution and Regime Characteristic

Karakteristik Lembaga dan Rezim yang sedangBerkuasa;

3. Compliance and Responsiveness

Tingkat Kepatuhan dan Adanya Respon dariPelaksana.

Terkait tata ruang kota, Mirsa (2011: 15) mengatakan bahwa: "dalam perencanaan, perancangan dan pemrograman prasarana kota, hal utama yang perlu diperhatikan terhadap elemen tata ruang kota itu sendiri adalah penyusunan perencanaan, pemanfaatan dan pengendalian". Dengan memperhatikan hal tersebut, pemanfaatan dari unsur-unsur atau elemen-elemen dari tata ruang kota yang dalam hal ini adalah Kota Administrasi Jakarta Utara akan lebih terarah terutama dalam mewujudkan pembangunan kota yang berwawasan lingkungan. Dalam perencanaan kota itu sendiri dikenal istilah ruang terbuka (open space) yaitu tempat terbuka di lingkungan perkotaan, ruang terbuka itu terdiri atas ruang terbuka hijau dan ruang terbuka non hijau (Pancawati, 2010:6).

Ruang terbuka hijau di wilayah perkotaan merupakan bagian dari penataan ruang kota yang berfungsi sebagai kawasan hijau pertamanan kota, kawasan hijau hutan kota, kawasan hijau rekreasi kota, kawasan hijau kegiatan olahraga kota, kawasan hijau pemakaman, kawasan hijau pertanian, kawasan hijau jalur hijau, dan kawasan hijau pekarangan (Fattah, 2001: 11).

Masalah penelitian

dapat

diidentifikasikan sebagai berikut:

1. Persentase luas ruang terbuka hijau di Jakarta Utara belum memenuhi standar yang telah ditetapkan dalam undangundang maupun peraturan daerah yang ada;

2. Adanya peningkatan alih fungsi lahan terbukahijau untuk pembangunan fisik;

3. Kurangnya pengelolaan terhadap ruang terbuka hijau yang sudah ada;

4. Adanya peningkatan jumlah penduduk di Jakarta Utara tiap tahunnya namun tidak diiringi dengan pertambahan lahan;

5. Masih kurangnya pengawasan terhadap pengelolaan dan penyediaan ruang terbuka hijau;

6. Tidak seimbangnya pertumbuhan pembangunan fisik dengan ketersediaan lahan terbuka hijau di Jakarta Utara.

Dari permasalahan yang diuraikan di atas, maka penulis membatasi masalah pada implementasi kebijakan ruang terbuka hijau di Kota Administrasi Jakarta Utara terkait dengan persentase luasan yang belum memenuhi standar. Adapun rumusan masalah sebagai berikut: 
1. Bagaimana implementasi kebijakan ruang terbuka hijau di KotaAdministrasi Jakarta Utara?

2. Apa saja kendala yang dihadapi dari implementasi kebijakan ruang terbuka hijau di KotaAdministrasi Jakarta Utara?

3. Upaya apa saja yang dilakukan untuk meningkatkan implementasi kebijakan ruang terbuka hijau di Kota Administrasi Jakarta Utara?

\section{METODELOGI}

Dalam penelitian yang dilaksanakan, penulis menggunakan metode deskriptif dimana penulis akan menggambarkan atau mendeskripsikan secara sistematis dan aktual mengenai fakta-fakta maupun fenomenafenomena yang dijumpai di lapangan pada saat penelitian terkait dengan implementasi kebijakan ruang terbuka hijau di Kota Administrasi Jakarta Utara. Adapun pendekatan penelitian yang digunakan penulis dalam penelitian ini adalah pendekatan induktif dimana kasus-kasus atau fenomena-fenomena khusus yang dijumpai penulis di lapangan nantinya akan menjadi bahan untuk diperolehnya suatu kesimpulan. Adapun alur pikir dari penelitian ini digambarkan dalam kerangka pemikiran yang tergambar sebagai berikut:

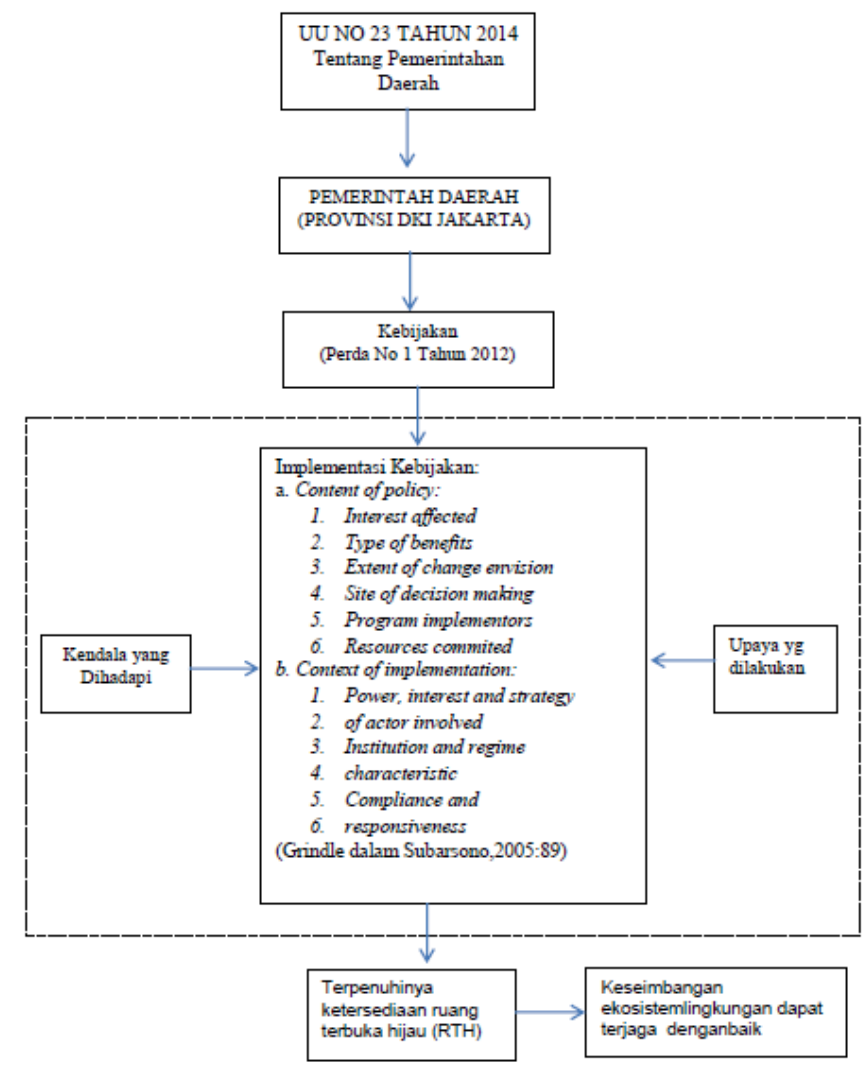

Sumber: Data diolah peneliti tahun 2017

\section{HASIL PENELITIAN DAN PEMBAHASAN}

Perubahan Luas RTH di Kawasan Jakarta Utara

Ruang terbuka hijau di Jakarta Utara cenderung mengalami perubahan luas setiap tahunnya. pada periode 2007-2014 terjadi pengurangan luas RTH sebesar 208,36 ha dari 937,01 ha pada tahun 2007 menjadi 728,65 ha pada tahun 2014. Pengurangan luas RTH terjadi karena adanya peningkatan jumlah penduduk di Jakarta Utara tiap tahunnya tetapi tidak diiringi dengan pertambahan lahan.

Lahan untuk RTH dialihfungsikan untuk pembangunan hunian dan kebutuhan prasarana kota. Selain itu, cepatnya peningkatan harga lahan di kawasan Jakarta Utara menyebabkan lahan menjadi suatu 
komoditas yang menguntungkan sehingga banyak orang berlomba-lomba untuk membangun lahan tersebut menjadi perumahan atau kawasan perdagangan yang dapat memberikan keuntungan daripada membangun taman. Akibatnya, luasan RTH menjadi semakin berkurang dari waktu ke waktu.

\section{RTH Jakarta Utara Berdasarkan Rencana Tata Ruang Wilayah (RTRW) Tahun 2011- 2030 DKI Jakarta}

Penyediaan RTH merupakan amanat dari Undang-Undang Nomor 26 Tahun 2007 tentang Penataan Ruang dimana di dalamnyadiisyaratkan bahwa luas RTH kota minimal harus sebesar 30\% dari luas total wilayah perkotaan. Pada kenyataannya terjadi penurunan kuantitas RTH yang sangat signifikan dikawasan perkotaan yang menyebabkan menurunnya kualitas ruang terbuka publik perkotaan. Oleh karena itu, salah satu langkah yang harus diambil terutama oleh para pembuat keputusan yaitu menyusun kebijakan hijau.

Adapun kebijakan yang telah dikeluarkan oleh Pemerintah DKI Jakarta terkait penyediaan RTH adalah berupa Peraturan Daerah Nomor 1 Tahun 2012 tentang Rencana Tata Ruang Wilayah 2030 DKI Jakarta yang merupakan rencana tata ruang wilayah Provinsi DKI Jakarta yang terdiri dari rencana tata ruang provinsi, rencana tata ruang kota administrasi yang di dalamnya termasuk Kota Administrasi Jakarta Utara, dan rencana tata ruang kabupaten administrasi. Dalam peraturan ini ditegaskan kembali bahwa keberadaan RTH memegang peranan yang sangat penting dalam kelangsungan hidup manusia. Untuk wilayah Jakarta Utara sendiri, keberadaan RTH diarahkan untuk fungsi dan manfaat sebagai berikut:

a. Sebagai fasilitas pelayanan umum untuk masyarakat seperti untuk melakukan kegiatan aktif dan pasif, antaralain: rekreasi, olahraga, wisata hutan, dan lainlain;

b. Sebagai pengaman yang sangat penting dalam upaya meningkatkan daya resap tanah terhadap air hujan ke dalamtanah;

c. Sebagai penyeimbang iklim mikro yang muncul akibat kemajuanteknologi;

d. Sebagai pengendali bahan-bahan polutan sehingga pencemaran dapat ditekan seminimal mungkin;dan

e. Sebagai habitat satwa liar dan tempat konservasi plasma nutfah serta tempat keanekaragaman hayati.

\section{Implementasi Kebijakan Ruang Terbuka Hijau di Kota Administrasi Jakarta Utara} Isi Kebijakan

a. Kepentingan yang Mempengaruhi Kebijakan Rencana Tata Ruang Wilayah dalam Penyediaan Ruang Terbuka Hijau

Dalam hal penyediaan ruang terbuka hijau Jakarta Utara, pemerintah mengacu pada beberapa kebijakan yang terkait. Kebijakan ini adalah kebijakan yang diterapkan pada tingkat nasional dan tingkat lokal itu sendiri. Kebijakan ini dianggap memiliki efek pada bagaimana cara pemerintah mengatur dan mengelola RTH perkotaan tanpa ada kepentingankepentingan lainyang mempengaruhi didalamnya.Pelaksanaan kebijakan Rencana Tata Ruang Wilayah dalam Penyediaan Ruang Terbuka Hijau di Jakarta Utara telah dijalankanberdasarkan arahan yang ada tanpa 
pengaruh dari kepentingan-kepentingan dalam bentuk apapun yang dapat menghambatterwujudnya implementasi kebijakantersebut.

b. Jenis Manfaat yang Dihasilkan dari Kebijakan Rencana Tata Ruang Wilayah dalam Penyediaan Ruang Terbuka Hijau.

Penyediaan dan pemanfaatan RTH di Jakarta Utara dalam RTRW DKI Jakarta 2030 dimaksudkan untuk menjamin tersedianya ruang yang cukup bagi:

1. Kawasan konservasi untuk kelestarian hidrologis;

2. Area pengembangan keanekaragaman hayati;

3. Area penciptaan iklim mikro dan pereduksi polutan;

4. Tempat rekreasi dan olahraga masyarakat;

5. Tempat pemakaman umum;

6. Pembatas perkembangan kota ke arah yang tidak diharapkan; dan

7. Pengamanan sumber daya alam, buatan maupun historis.

c. Derajat Perubahan yang Ingin Dicapai dari Kebijakan Penyediaan Ruang Terbuka Hijau.

Kondisi saat ini menunjukkan bahwa Jakarta Utara kurang memiliki RTH. Dalam Rencana Tata Ruang Wilayah (RTRW) Jakarta 2011-2030, pemerintah telah menyiapkan target RTH sebesar $13,94 \%$ dari luas wilayahnya. Ini berarti bahwa pemerintah perlu memberikan tambahan $8,94 \% \mathrm{RTH}$ dari RTH eksisting saat ini. Dengan peningkatan luasan RTH yang kurang dari 1\% dalam kurun waktu 10 tahun terakhir, maka akan memakan waktu yang lama untuk wilayah Jakarta Utara dalam mewujudkan target RTH yang ingin dicapai, apalagi untuk memiliki jumlah ideal RTH sesuai kebutuhan.

d. Kedudukan Implementor Kebijakan Rencana Tata Ruang Wilayah dalam Penyediaan Ruang Terbuka Hijau.

Implementor kebijakan tentunya mempunyai peranpenting dalam melaksanakan kebijakan yang telah ditetapkan yang dalam hal ini adalah kebijakan Rencana Tata Ruang Wilayah dalam Penyediaan Ruang Terbuka Hijau di Jakarta Utara. Peran implementor kebijakan tentunya dapat menjadi tolak ukur keberhasilan implementasi kebijakan dalam penyediaan RTH di Jakarta Utara. Artinya, apabila implementasi kebijakan RTH belum secara optimal direalisasikan maka peran implementor kebijakan dipertanyakan.
e. Pelaksana Program Penyediaan Ruang TerbukaHijau

Dalam hal penyediaan, pemeliharaan dan pengendalian ruang terbuka hijau Jakarta Utara dilakukan oleh dinas-dinas maupun suku dinas yang sesuai dengan lokasi ruang terbuka hijau yang akan disediakan maupun yang sudah tersedia, diantaranya adalah Suku Dinas Pertamanan dan Pemakaman Jakarta Utara di bawah koordinasi Dinas Pertamanan dan Pemakaman Provinsi DKI Jakarta dan Suku Dinas Tata Ruang Jakarta Utara di bawah koordinasi Dinas Tata Ruang Provinsi DKI Jakarta. Adapun dalam hal perencanaan, pelaksanaan dan hasil evaluasi penyediaan, pemanfaatan dan pengendaliannya dikoordinasikan terlebih dahulu dengan Badan Perencanaan Pembangunan Daerah Provinsi DKI Jakarta. 
f. Sumber Daya yang Digunakan dalam Penyediaan Ruang Terbuka Hijau

Dalam pelaksanaan suatu kegiatan tentunya akan membutuhkan sumber daya yang potensial untuk mendukung keberhasilan terlaksananya kegiatan tersebut. Begitu juga halnya dengan penyediaan ruang terbuka hijau. Untuk wilayah Jakarta Utara sendiri, sumber daya yang digunakan dalam penyediaan ruang terbuka hijau masih sangat terbatas dalam hal personil (sumber daya manusia).

\section{Lingkungan Implementasi}

a. Kekuasaan, kepentingan dan strategi dari Aktor yang terlibat dalam penyediaan Ruang Terbuka Hijau di Kota Administrasi Jakarta Utara.

Terkait dengan penyediaan ruang terbuka hijau di Jakarta Utara, kekuasaan dan kepentingan dari aktor yang terlibat di dalamnya tidak dominan berpengaruh terhadap kebijakan tersebut. Dalam hal ini suku dinas-suku dinas terkait seperti Suku Dinas Pertamanan dan Pemakaman Jakarta Utara dan Suku Dinas Tata Ruang Jakarta Utara sebagai stakeholders langsung di lapangan memegang peranan penting dalam hal penyediaan RTH sesuai dengan rencana tata ruang dan wilayah yang ada. Dalam pelaksanaannya, suku dinas-suku dinas tersebut selalu berkoordinasi dengan dinasdinas yang terkait langsung, yang dalam hal ini adalah Dinas Pertamanan dan Pemakaman Provinsi DKI Jakarta dan Dinas Tata Ruang Provinsi DKI Jakarta. Adanya koordinasi tersebut dilakukan adalah untuk menghindari munculnya kepentingan-kepentingan lain yang dapat menghambat pelaksanaan dari penyediaan RTH tersebut. b. Karakteristik Lembaga atau Institusi yang akan Turut Mempengaruhi Penyediaan Ruang Terbuka Hijau di Kota Administrasi Jakarta Utara

Penyediaan RTH di Jakarta Utara melibatkan institusi yang berbeda dalam struktur organisasi pemerintahannya.Instansi teknis yang memiliki tanggung jawab dalam penyediaan RTH di Jakarta Utara adalah Suku Dinas Pertamanan dan Pemakaman Jakarta Utara yang berkoordinasi dengan Dinas Pertamanan dan Pemakaman Provinsi DKI Jakarta dan Suku Dinas Tata Ruang Jakarta Utara yang berkoordinasi dengan DinasTata Ruang Provinsi DKI Jakarta. Suku dinas-suku dinas ini bekerja sama dengan institusi lain dalam melaksanakan tugas dan fungsinya dalam penyediaan RTH.

Kendala yang dihadapi dari Implementasi Kebijakan Ruang Terbuka Hijau di Kota Administrasi Jakarta Utara adalah sebagai berikut:

1. Lemahnya pengawasan terhadap penggunaan lahan dan bangunan.

2. Masih adanya intervensi berbagai pihak mengakibatkan pengawasan terhadap pelanggaran ketentuan penggunaan lahan dan bangunan menjadi lemah. Selain itu, pengawasan yang dilakukan Pemerintah Jakarta Utara dalam hal ini instansi terkait yang mengeluarkan perizinan hanya dapat dilakukan saat masyarakat mengajukan permohonan perizinan. Lemahnya pengawasan pada dasarnya dikarenakan tidak adanya ketentuan hukum yang menegaskan pembolehan penertiban terhadap bangunan yang menggunakan lahan RTH. 
3. Harga tanah yang mahal

Penyediaan RTH di perkotaan dihadapkan pada terbatasnya tanah yang dikuasai pemerintah sedangkan tanah yang tidak terbangun harus dibeli pemerintah dengan mahal secara bertahap karena anggaran pemerintah yang tidak mencukupi dan adanya sektor-sektor yang juga memerlukan pembiayaan. Penahapan-penahapan dalam pembelian tanah juga menghadapi tingginya tingkat pembangunan fisik oleh masyarakat sehingga harus diperhitungkan kemungkinan tidak tersedianya tanah yang tidak terbangun di masa yang akan datang.

4. Peningkatan LahanTerbangun

Di Jakarta Utara, dibeberapa kecamatan, lahan-lahan yang semestinya dapat dimanfaatkan sebagai RTH justru berubah menjadi bangunan-bangunan pertokoan, gedung perkantoran, perumahan dan sebagainya. Di Kecamatan Cilandak misalnya, peruntukan lahan untuk RTH dibangun pertokoan. Kemudian di Kecamatan Pasar Minggu terdapat bangunan perbankan, di Kecamatan Jagakarsa dibangun sekolah dan perumahan, bangunan perkantoran di Kecamatan Pancoran, dan fasilitas jalan di Kecamatan Setiabudi.

Berdasarkan data yang diperoleh dari Suku Dinas Tata Ruang Jakarta Utara bahwa luas kawasan terbangun di Jakarta Utara tahun 2015 adalah 7.836,50 Ha sehingga luas lahan Jakarta Utara yang dapat dimanfaatkan untuk RTH adalah 6.736,50 Ha dan sudah termasuk luas RTH saat ini serta lahan terbuka yang belum dimanfaatkan baik milik pemerintah maupun masyarakat.

5. Kurangnya sosialisasi kepada masyarakat Pasal 2 (dua) poin c Peraturan Menteri Pekerjaan Umum Nomor 5 Tahun 2008 menyatakan bahwa maksud dari Pedoman Penyediaan dan Pemanfaatan Ruang Terbuka Hijau di Kawasan Perkotaan adalah memberikan bahan sosialisasi publik mengenai arti pentingnya ruang terbukahijau bagi kehidupan masyarakat perkotaan dan pada poin " $\mathrm{d}$ " untuk memberikan informasi yang seluas-luasnya kepada masyarakat dan pihak-pihak terkait tentang perlunya ruang terbuka hijau sebagai pembentuk ruang yang nyaman untuk beraktivitas dan bertempat tinggal. Namun, sosialisasi yang dilakukan mengenai RTH di Jakarta Utara belum maksimal padahal pelibatan masyarakat dalam penyediaan RTH sangat diperlukan. Sektor pendidikan formal di Jakarta Utara juga tidak memberikan pendidikan tentang pentingnya RTH sehingga kesadaran terhadap RTH sejak anak-anak hingga dewasa tidak terbentuk.

Upaya-Upaya yang Dilakukan untuk Meningkatkan Penyediaan Ruang Terbuka Hijau Di Kota Administrasi Jakarta Utara

1. Persyaratan Penyediaan RTH pada Penerbitan Izin Mendirikan Bangunan (IMB) Peningkatan lahan terbangun di Jakarta Utara dan terbatasnya tanah pemerintah serta dana untuk membeli lahan masyarakat mengakibatkan penyediaan RTH menjadi sulit. 
Pemerintah Jakarta Utara memerlukan inovasi kebijakan agar antara kebutuhan pembangunan fisik dan RTH dapat bersesuaian. Oleh karena iturencana penyediaan RTH privat melalui penerbitan Izin Mendirikan Bangunan (IMB) sebagai upaya untuk mengatasi permasalahan tersebut. Hal ini merupakan inovasi dari kebijakan sebelumnya yang hanya memberikan plot pada proses perizinan.

\section{Pembeliantanah}

Tanah merupakan aset yang berharga secara ekonomi maupun sosial bagi masyarakat baik di perkotaan maupun pedesaan. Tanah yang berada di perkotaan penggunaannya selalu dilakukaan secara maksimal maka harga tanah di perkotaan lebih mahal dibandingkan di pedesaan. Namun, tanah di perkotaan sebagian besar sudah dikuasai masyarakat sehingga pemerintah kesulitan dalam memberikan pengaruh terhadap tata ruang kota termasuk ruang terbuka hijau. Pembebasantanahdengancaramembelitanah masyarakatmerupakansalahsatuupayayang ditempuh pemerintah Jakarta Utara dalam menyediakan RTH. Berdasarkan data materi teknis RTRW Jakarta Utara, Pengadaan Tanah untuk Taman \& TPU akan dilakukan dari awal hingga akhir periode RTRW Jakarta Utara.

\section{Pemanfaatan lahan publik}

Jakarta Utara mempunyai median jalan yang lebar, seperti Jalan Setiabudi memiliki lebar median jalan \pm 3-4 meter dan belum termasuk sempadan jalan yang pada umumnya lebih lebar dibandingkan median jalannya. Pemanfaatan areal-areal tersebut sebagai RTH tentunya akan sangat menguntungkan bagi penambahan ketersediaan RTH Jakarta Utara. Oleh karena itu, pemanfaatan areal atau lahan publik tersebut selain memberikan nilai estetika, namun juga menyeimbangkan lingkungan dengan fungsinya sebagai ruang terbuka hijau di Jakarta Utara.

4. Penyediaan RTH Melalui Taman Atap (Roof Garden)

Taman atap (roof garden) merupakan salah satu sarana untuk menyediakan RTH di perkotaan. Pengelola RTH di Jakarta Utara merencanakan untuk mengajukanpembuatan kebijakan mengenai taman atap kepada Pemerintah Provinsi DKI Jakarta sebagai upaya untuk menyediakan kekurangan luas RTH. Permenpu Nomor 5 Tahun 2008 tentang Pedoman Penyediaan dan Pemanfaatan Ruang Terbuka Hijau di Kawasan Perkotaan menyatakan bahwa taman atap dapat dilakukan pada kondisi luas lahanterbuka terbatas atau lahan dengan Koefisien Dasar Bangunan (KDB) di atas 90\%, seperti pada kawasan pertokoan di pusat kota, atau pada kawasan-kawasan dengan kepadatan tinggi. Oleh karena itu, rencana Taman atap (roof garden) ini akan diterapkan pada kawasankawasan yang padat dengan bangunanbangunan beratap semen.

\section{KESIMPULAN}

Berdasarkan hasil penelitian dan pembahasan yang telah diuraikan, maka kesimpulan yang diperoleh antaralain:

1. Implementasi kebijakan Rencana Tata Ruang Wilayah dalam Penyediaan Ruang Terbuka Hijau di Kota Administrasi Jakarta Utara masih belum optimal dan baru terealisasi sebesar 5\%. Hal ini dikarenakan penggunaan lahan yang tersedia untuk RTH tidak difungsikan sebagaimana peruntukannya. Sementara itu, proses kebijakan penyediaan RTH itu masih 
berada pada tataran formulatif yaitu dengan dirumuskannya Peraturan Daerah Nomor 1 Tahun 2012 tentang Rencana Tata Ruang Wilayah 2030 tetapi secara implementatif sebagaimana Perda itu dijalankan oleh Suku Dinas Pertamanan dan Pemakaman sebagai leading sector dalam upaya penyediaan RTH masih banyak menemui kendala.

2. Kendala-kendala yang dihadapi dalam mewujudkan implementasi kebijakan Rencana Tata Ruang Wilayah dalam Penyediaan Ruang Terbuka Hijau di Kota Administrasi Jakarta Utara antara lain: (a) lemahnya pengawasan terhadap penggunaan lahan dan bangunan; (b) harga tanah yang mahal; (c) peningkatan lahan terbangun; dan (d) kurangnya sosialisasi kepada masyarakat mengenai arti pentingnya ruang terbukahijau bagi kehidupan masyarakat perkotaan

3. Upaya-upaya yang dilakukan dalam mewujudkan implementasi kebijakan Rencana Tata Ruang Wilayah dalam Penyediaan Ruang Terbuka Hijau di Kota Administrasi Jakarta Utara antara lain: (a) persyaratan penyediaan RTH pada penerbitan Izin Mendirikan Bangunan (IMB); (b) pembelian tanah masyarakat oleh pemerintah; (c) pemanfaatan lahan publik sebagai ruang terbuka hijau; dan (d) penyediaan RTH melalui taman atap (roof garden) pada kawasan-kawasan yang padat dengan bangunan-bangunan beratap semen.

Sebagai masukan, hasil penelitian ini memberikan masukan-masukan kepada pemangku kebijakan, antara lain sbagai berikut:
1. Perlunya sebuah political will dari pemerintah untuk mewujudkan ketersediaan ruang terbuka hijau sesuai dengan amanat dari undang-undang yakni minimal sebesar 30\%, mengingat bahwa RTH kota tidaklah hanya sekedar pelengkap suatu Rencana Umum Tata Ruang Kota tetapi lebih dariitu keberadaan RTH kota adalah sebagai "alat kendali" kerusakan (fisik) lingkungan lebih lanjut.

2. Perlu adanya suatu kajian oleh pemerintah untuk menjadikan Jakarta hanya sebagai pusat pemerintahan saja, mengingat bahwa selama ini peran Jakarta sebagai pusat ekonomi, bisnis, pariwisata dan juga pemerintahan membuat padatnya penduduk sehinggaberdampakpadatidakterkendalin ya pemanfaatan ruang-ruang kota khususnya ruang terbukahijau.

3. Pemerintah perlu melakukan pengawasan yang lebih ketat terhadap penyediaan ruang terbuka hijau serta adanya pemberlakuan sanksi yang tegas kepada siapapun yang melanggar aturan terkait penyediaan ruang terbukahijau.

\section{DAFTAR PUSTAKA}

Bambang. 1994. Hukum dan Kebijaksanaan Publik. Jakarta: Sinar Grafika.

Fattah, N. 2001. Perencanaan Kota Komprehensif. Bandung: Angkasa. Hamdi, M. 1999. Bunga Rampai Pemerintahan. Jakarta: Yarsif Watampone.

Jenks, Mike dan Nicola Jones. 2010. Future Form and Design for Sustainable 
Cities. New York: Overlook Press. Mirsa, Rinaldi. 2011. Elemen Tata Ruang Kota. Yogyakarta: Graha Ilmu.

Nugroho, Riant. 2012. Public Policy: Teori, Manajemen, Dinamika, Analisis, Konvergensi dan Kimia Kebijakan (Edisi 5). Jakarta: Elex Media Komputindo.

Pancawati, Tuti. 2010. Tata Ruang Perkotaan. Yogyakarta: Pustaka Pelajar.

Subarsono, A.G. 2005. Analisis Kebijakan Publik: Konsep, Teori dan Aplikasi. Yogyakarta: Pustaka Pelajar. Sunggono,

\section{Peraturan Perundang-Undangan}

Undang-Undang Nomor 26 Tahun 2007 tentang Penataan Ruang.

Peraturan Menteri Pekerjaan Umum Nomor 05/PRT/M/2008 tentang Pedoman Penyediaan dan Pemanfaatan Ruang Terbuka Hijau di Kawasan Perkotaan.

Peraturan Daerah Provinsi DKI Jakarta Nomor 1 Tahun 2012 tentang Rencana Tata Ruang Wilayah 2030. 